\title{
KADAR SECRETORY IMMUNOGLOBULIN A DAN HUMAN B DEFENSIN-2 TINJA PADA NEONATUS PREMATUR YANG MENDAPAT AIR SUSU IBU SAJA, SUSU FORMULA SAJA, DAN KOMBINASINYA
}

\author{
Putri Primawardani $^{\star \bowtie}$, Eko Sulistijono**, Hidayat Sujuti***
}

\begin{abstract}
Abstrak
Sekretori IgA dan human B-defensin-2 berperan penting dalam pertahanan saluran cerna. Penelitian ini bertujuan menilai SlgA dan hBD-2 tinja neonatus prematur (sebagai penanda inflamasi) terkait pemberian nutrisi. Penelitian dirancang secara cross sectional dengan 39 neonatus prematur yang dibedakan menjadi kelompok ASI saja, susu formula saja, serta kombinasinya. Kadar SlgA dan hBD-2 tinja diukur dengan ELISA, dan dianalisis secara statistik. Kadar SIgA tinja neonatus prematur yang mengonsumsi ASI saja lebih tinggi bermakna $(p<0,005)$. Kadar hBD-2 pada kelompok yang mengonsumsi susu formula saja lebih tinggi namun tidak berbeda bermakna $(p=0,463)$ dengan kelompok kombinasi. Kesimpulan penelitian ini, kadar slgA tinja neonatus yang mengonsumsi ASI saja lebih tinggi bermakna. Kadar human ß-defensin-2 tinja neonatus prematur yang mengonsumsi susu formula saja lebih tinggi, namun tidak berbeda bermakna dengan kelompok kombinasi.
\end{abstract}

Kata kunci: hBD-2, prematur, sekretori lgA, tinja.

\section{LEVELS OF FECAL SECRETORY IMMUNOGLOBULIN A AND HUMAN ß-DEFENSIN-2 IN PRETERM NEONATES FED ON BREAST MILK, FORMULA, AND THEIR COMBINATION}

\begin{abstract}
Secretory immunoglobulin A and human B-defensin-2 play an important role in the digestive system defense. This study aims to assess fecal SlgA and hBD-2 in preterm neonates (as inflammation marker) with different feeding patterns. This study was cross-sectionally designed included 39 preterm neonates which categorized into breast milk only, formula milk only, and their combination. Fecal SIgA and hBD-2 measured by ELISA, then statistical analysis was performed. Results showed that fecal Slga in breast milk only were significantly higher $(p<0.005)$. Fecal hBD-2 in formula milk only was higher but not significantly different ( $p=0.463$ ) with the combination group. It can be concluded, fecal SlgA level that consumed breast milk only was significantly higher. Fecal hBD-2 level that consumed formula milk only was higher but not significantly different with the combination group.

Keywords: hBD2, fecal, secretory lgA, preterm.

* Program Magister (S2) IImu Biomedik, Fakultas Kedokteran, Universitas Brawijaya

** Departemen IImu Kesehatan Anak, Fakultas Kedokteran, Universitas Brawijaya-RS. Dr. Saiful Anwar Malang

*** Departemen Biokimia-Biomolekuler, Fakultas Kedokteran, Universitas Brawijaya

E-mail: putriprimawardani@gmail.com
\end{abstract}




\section{Pendahuluan}

Kelahiran prematur mempengaruhi kirakira satu dari sepuluh kelahiran hidup di seluruh dunia. Sepsis neonatal banyak terjadi pada neonatus prematur dengan prevalensi meningkat dari $2 \%$ pada neonatus dengan usia kehamilan 32 sampai $>37$ minggu (moderately preterm infants), $10-20 \%$ pada neonatus dengan usia kehamilan 28 sampai 32 minggu (very preterm infants), dan 30-40\% pada neonatus dengan usia kehamilan $<28$ minggu (extremely preterm infants). ${ }^{1}$ Bukti klinis menunjukkan bahwa etiologi patogen sepsis neonatal dapat terjadi karena translokasi dari saluran pencernaan neonatus. ${ }^{2}$ Terkait hal tersebut, dibutuhkan strategi untuk mengurangi masalah saluran cerna pada neonatus prematur, salah satunya yakni pemberian nutrisi optimal dengan air susu ibu. ${ }^{3}$

Sekretori imunoglobulin A merupakan salah satu marker integritas saluran cerna yang dapat dideteksi pada tinja neonatus. Antibodi ini dalam bentuk dimer disebut sebagai sekretori imunoglobulin A yang membentuk pertahanan terhadap toksin dan organisme patogen yang berperan protektif terhadap infeksi. Oleh karena itu, slgA dianggap sebagai penanda kesehatan saluran cerna. ${ }^{4}$

Selain sekretori imunoglobulin, peptida juga merupakan substansi bioaktif untuk menilai inflamasi saluran cerna. Beberapa peptida teridentifikasi pada mekonium dan tinja neonatus selama minggu pertama kehidupan, salah satunya adalah defensin. ${ }^{5}$ Defensin yang disekresi pada epitel terutama saluran cerna dan berhubungan dengan reaksi inflamasi yakni human beta defensin 2 (hBD-2).

Biomarker tinja menjadi salah satu pilihan pemeriksaan yang tidak invasif dan diharapkan mampu merefleksikan inflamasi serta kondisi patologis spesifik pada

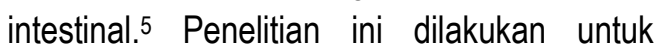

mengetahui kadar sekretori imunoglobulin A (SlgA) dan hBD-2 tinja sebagai biomarker inflamasi mukosa saluran cerna pada neonatus prematur yang mengonsumsi ASI saja, susu formula saja, maupun kombinasi pada usia empat belas hari.

\section{Bahan dan Metode}

\section{Desain Penelitian}

Penelitian ini merupakan penelitian prospektif analitik menggunakan rancangan studi cross sectional dilakukan di ruang neonatologi Rumah Sakit Umum Daerah Dr. Saiful Anwar (RSSA) Malang serta Laboratorium Fisiologi Fakultas Kedokteran Universitas Brawijaya Malang selama tiga bulan dan telah disetujui oleh tim etik RSSA dengan nomor surat: 400/010/K.3/302/2019.

\section{Populasi dan Subjek}

Populasi penelitian yaitu neonatus kurang bulan (usia gestasi $\leq 32$ minggu) yang dirawat di ruang perinatologi RSSA sejak 1 Juni-31 Agustus 2019. Adapun kriteria inklusi yakni neonatus prematur dengan skor APGAR >5 pada menit kelima; neonatus prematur tanpa kelainan kongenital maupun kelainan bedah saluran cerna; riwayat ibu dengan IMT $18-25 \mathrm{~kg} / \mathrm{m}^{2}$ sebelum hamil; riwayat ibu tidak mengalami chorioamnionitis yang ditandai dengan leukosit lebih dari $20000 / n l$ dan temperatur lebih dari $38^{\circ} \mathrm{C} .6$ Kriteria eksklusi yakni neonatus prematur yang tidak dilahirkan di RS. Saiful Anwar Malang (rujukan); neonatus prematur dengan Kecil Masa Kehamilan (KMK) maupun Besar Masa Kehamilan (BMK); neonatus prematur dengan kelainan endokrin maupun kelainan kromosom; riwayat ibu dengan penyakit autoimun maupun penyakit kronis lainnya.

Sampel diambil pada neonatus usia 14 hari. Didapatkan 39 sampel yang dibagi ke dalam tiga kelompok yaitu tinja dari neonatus prematur yang mengonsumsi ASI saja, susu formula saja, ASI dan susu formula. 
Persiapan Sampel Tinja

Sampel diambil dari tinja pada diaper menggunakan spatula. Transpor sampel menggunakan tabung yang bersih, serta pengiriman kurang dari 30 menit menggunakan wadah khusus yang dapat menjaga suhu tetap stabil.

\section{Perhitungan Kadar SIgA dan hBD-2}

Kadar SlgA tinja diukur dengan metode enzyme-linked immunosorbent assay (ELISA) menggunakan human secretory immunoglobulin A ELISA Kit Bioassay Technology Laboratory, sementara hBD-2 menggunakan Human Beta Defensin 2 ELISA Kit Bioassay Technology Laboratory. Kadar SlgA dan hBD2 tinja diukur jika sampel telah dilakukan homogenisasi dan diekstrak dengan wash buffer. Sediaan wash buffer concentrate (25x) diambil $20 \mathrm{~mL}$ diencerkan dengan deionized atau distilled water sampai dengan $500 \mathrm{~mL}$. Sejumlah $10 \mathrm{~mL}$ washbuffer ditambahkan untuk setiap $100 \mathrm{mg}$ sampel tinja (1:100) kemudian dikocok menggunakan vorteks selama 5 menit, $1 \mathrm{~mL}$ dari campuran larutan tersebut dimasukkan dalam eppendorf dan disentrifus selama 20 menit (2000-3000 RPM) sehingga diperoleh supernatan. Hasil ekstraksi dapat bertahan selama 1 bulan bila disimpan pada suhu $-20{ }^{\circ} \mathrm{C}$. Sebelum dianalisis, dilakukan pengenceran supernatan 1:10 (100 $\mu \mathrm{L}+900 \mu \mathrm{L}$ wash buffer) untuk pemeriksaan SlgA dan 1:100 $(1 \mu \mathrm{L}+100 \mu \mathrm{L}$ wash buffer) dilakukan dua kali untuk pemeriksaan hBD-2. Adapun yang digunakan untuk setiap well adalah $100 \mu \mathrm{L}$ dari supernatan yang telah diencerkan. Selanjutnya menyiapkan larutan standar yang akan dikalkulasi dengan optical density dari intensitas warna masing-masing sampel untuk mengetahui konsentrasi slgA. Pada penelitian ini menggunakan 5 standard solution dan melakukan assay procedure sesuai dengan user instruction pada ELISA kit. Hasil ELISA dibaca setelah 10 menit pemberian stop solution, intensitas warna yang terbentuk diukur menggunakan ELISA reader set to $450 \mathrm{~nm}$ wavelength filter dan akan didapatkan nilai optical density.

Analisis Statistik

Data dikumpulkan dari hasil pengukuran

SlgA dan hBD-2 kelompok yang mendapatkan ASI saja, ASI dan susu formula, serta susu formula saja. Analisis data menggunakan uji normalitas kemudian uji komparatif untuk mencari perbedaan pada tiap kelompok dan diolah menggunakan software SPSS. Hasil

\section{Karakteristik Sampel}

Karakteristik dasar sampel penelitian yang diamati adalah karakteristik dasar neonatus (jenis kelamin, cara persalinan, usia kehamilan, berat badan lahir, panjang badan lahir, dan lingkar kepala), serta ibu (preeklampsia, eklampsia, riwayat ketuban pecah dini, dan kehamilan gemeli). Setiap karakteristik dilakukan analisis menggunakan chi square dengan nilai $p>0,05$ yang berarti tidak didapatkan perbedaan signifikan antar masing-masing kelompok.

\section{Kadar Sekretori Imunoglobulin A dan Human} Beta Defensin 2 Tinja

Kadar SlgA tinja dijabarkan dalam $\mu \mathrm{g} /$ $\mathrm{mL}$ dengan nilai tertinggi pada kelompok neonatus prematur yang mengonsumsi ASI yaitu 2091,2 dan nilai terendah yaitu 194,77 pada kelompok susu formula saja. Kelompok ASI saja, kadar SIgA tinja $(835,8-2091,2)$ lebih tinggi dibandingkan kelompok neonatus prematur yang mengonsumsi ASI dan susu formula $(453,78$-1104,02) serta susu formula saja (194,77-714,87) (Gambar 2).

Kadar hBD-2 tinja dijabarkan dalam ng/ $\mathrm{mL}$ dimana nilai tertinggi diperoleh pada kelompok neonatus prematur yang mengonsumsi susu formula yakni 492 dan nilai terendah didapatkan pada kelompok ASI saja yakni 151,775. 
Kelompok neonatus prematur yang mengonsumsi ASI saja, kadar hBD-2 tinja (151,77-272,77) lebih rendah dibandingkan kelompok ASI dan susu formula maupun susu formula saja $(304,27-430,27$ dan 311,22492,27) (Gambar 3).
Hasil uji statistik Shapiro-Wilk diperoleh $p$-value $>0,05$, yang berarti data variabel kadar SIgA dan hBD-2 tersebut terdistribusi normal. Adapun perbedaan mean kadar SlgA dan hBD-2 tinja neonatus prematur berdasarkan uji ANOVA one way (analysis of variance) dapat dilihat pada Tabel 2.

Tabel 1. Karakteristik dasar sampel penelitian.

\begin{tabular}{|c|c|c|c|}
\hline Karakteristik & ASI & $\begin{array}{c}\text { ASI dan } \\
\text { Susu Formula }\end{array}$ & Susu Formula \\
\hline \multicolumn{4}{|l|}{ Jenis kelamin, $(\mathrm{n})$} \\
\hline Laki-laki & $6 / 13$ & $4 / 13$ & $4 / 13$ \\
\hline Perempuan & $7 / 13$ & $9 / 13$ & $9 / 13$ \\
\hline $\begin{array}{l}\text { Usia Kehamilan (minggu), } \\
\text { median (min_maks) }\end{array}$ & \multicolumn{3}{|c|}{$30(25-32)$} \\
\hline$<28$ & $2 / 13$ & $1 / 13$ & - \\
\hline $28-30$ & $4 / 13$ & $6 / 13$ & $5 / 13$ \\
\hline $30-32$ & $7 / 13$ & $6 / 39$ & $8 / 13$ \\
\hline Berat Lahir (gram), rerata (SD) & $1553,8( \pm 430,7)$ & $1459,7( \pm 406,5)$ & $1010( \pm 506,4)$ \\
\hline Panjang lahir, rerata $(\mathrm{SD})(\mathrm{cm})$ & $39,2( \pm 4,6)$ & $39,5( \pm 2,9)$ & $40,9( \pm 4,0)$ \\
\hline Lingkar kepala lahir, rerata (SD) (cm) & $28,2( \pm 2,1)$ & $27,8( \pm 1,7)$ & $28,4( \pm 1,8)$ \\
\hline Terapi oksigen (n) & $6 / 13$ & $7 / 13$ & $5 / 13$ \\
\hline \multicolumn{4}{|l|}{ Riwayat persalinan (n) } \\
\hline Normal & $7 / 13$ & $3 / 13$ & $3 / 13$ \\
\hline Sectio caesarian & $6 / 13$ & $10 / 13$ & $10 / 13$ \\
\hline \multicolumn{4}{|l|}{ Riwayat kehamilan ibu (n) } \\
\hline Preeklampsia & $3 / 13$ & $4 / 13$ & $6 / 13$ \\
\hline Eklampsia & - & - & $1 / 13$ \\
\hline Ketuban pecah dini & $3 / 13$ & $6 / 13$ & $6 / 13$ \\
\hline Kehamilan gemeli & $2 / 13$ & & - \\
\hline \multicolumn{4}{|l|}{ Klinis (n) } \\
\hline Distres napas & $6 / 13$ & $6 / 13$ & $6 / 13$ \\
\hline Muntah & $10 / 13$ & $9 / 13$ & $9 / 13$ \\
\hline Perut membesar & $9 / 13$ & $9 / 13$ & $5 / 13$ \\
\hline Penggunaan antibiotika (n) & $7 / 13$ & $9 / 13$ & $11 / 13$ \\
\hline
\end{tabular}

Tabel 2. Hasil uji komparatif kadar SlgA dan hBD-2 tinja neonatus prematur.

\begin{tabular}{|c|c|c|}
\hline Variabel Penelitian & Mean (SD) & $p$-value \\
\hline Sekretori $\lg A(S \lg A)(\mu g / m L)$ & & \multirow{4}{*}{$0.00^{*}$} \\
\hline ASI saja & $1541,92+418,69$ & \\
\hline ASI dan susu formula & $826,23+311,58$ & \\
\hline Susu formula saja & $387,66+135,96$ & \\
\hline \multicolumn{3}{|c|}{ Human 3 defensin 2 (hBD-2) (ng/mL) } \\
\hline ASI saja & $204,47+40,63$ & \multirow[b]{3}{*}{0,463} \\
\hline ASI dan susu formula & $351,66+38,19$ & \\
\hline Susu formula saja & $375,73+69,13$ & \\
\hline
\end{tabular}

Keterangan: $p$-value $<0,05=\operatorname{signifikan~}\left(^{*}\right)$ 
Kelompok neonatus prematur yang mengonsumsi ASI saja didapatkan dengan kadar mean SlgA tertinggi $(154192+418,69)$ yang berbeda bermakna dengan kedua kelompok neonatus prematur lainnya. Sementara itu, kelompok yang mengonsumsi susu formula saja memiliki mean hBD-2 tinja paling tinggi $(375,73+69,13)$, namun tidak berbeda bermakna dengan kelompok neonatus prematur yang mengonsumsi $\mathrm{ASI}$ dan susu formula $(p=0,463)$. Sebaliknya, mean kadar hBD-2 tinja neonatus prematur pada kelompok yang mengosumsi ASI saja berbeda bermakna $(p=0,00)$ terhadap kedua kelompok lainnya.

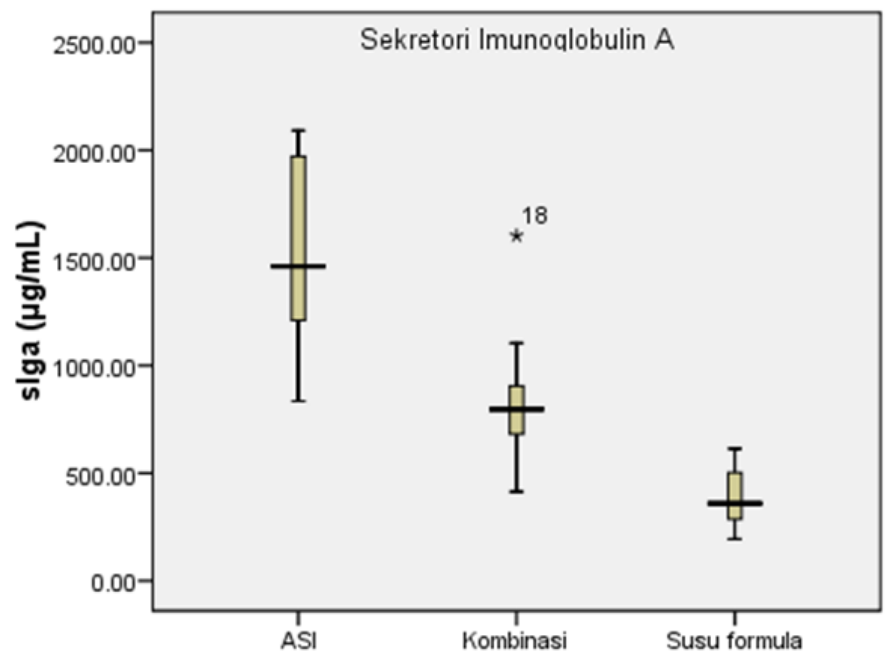

Gambar 2. Kadar slgA tinja neonatus prematur pada kelompok ASI saja, ASI dan susu formula, serta susu formula saja di hari keempat belas.

Keterangan: Kadar slgA tinja pada kelompok ASI lebih tinggi dibandingkan pada kelompok ASI dan susu formula serta susu formula saja; (a) Kelompok neonatus prematur yang mengonsumsi ASI saja; (b) kelompok neonatus prematur yang mengonsumsi ASI dan susu formula; (c) kelompok neonatus prematur yang mengonsumsi susu formula saja.

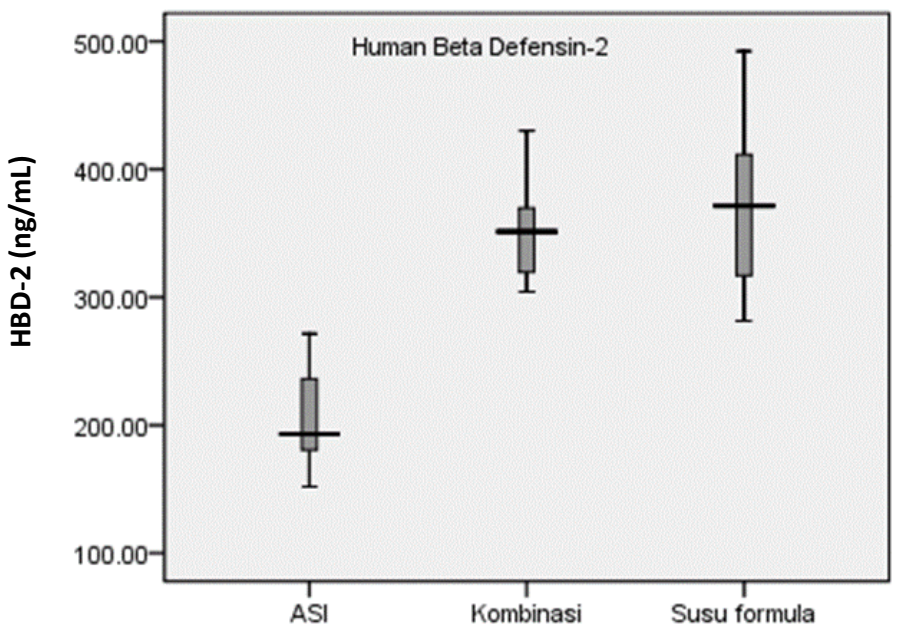

Gambar 3. Kadar HBD-2 tinja neonatus prematur pada kelompok ASI saja, ASI dan susu formula, serta susu formula saja dihari keempat-belas.

Keterangan: Kadar HBD-2 tinja pada kelompok ASI lebih rendah dibandingkan kadar HBD-2 tinja pada kelompok kombinasi ASI dan susu formula serta susu formula saja. (a) Kelompok neonatus prematur yang mengonsumsi ASI saja; (b) kelompok neonatus prematur yang mengonsumsi ASI dan susu formula; (c) kelompok neonatus prematur yang mengonsumsi susu formula saja. 


\section{Pembahasan}

Usia kehamilan neonatus yang menjadi sampel penelitian yakni <32 minggu dengan rentang usia kehamilan 25 sampai 32 minggu. Beberapa penelitian menjabarkan bahwa usia kehamilan berhubungan dengan inisiasi pemberian air susu ibu, seperti yang dilakukan oleh Maastrup et al., 2014 membuktikan bahwa semakin muda usia gestasi semakin sulit untuk pemberian ASI eksklusif oleh karena neonatus prematur mengalami kesulitan menetek langsung pada ibu dibandingkan neonatus aterm. Lebih dari $85 \%$ inflamasi saluran cerna terjadi pada neonatus dengan berat badan lahir $<1500$ gram atau usia kehamilan $<32$ minggu. ${ }^{7}$

Good et al. (2014) membuktikan kelahiran prematur merupakan faktor risiko utama kejadian enterokolitis nekrotikan, hal ini menggambarkan keadaan intestinal yang imatur pada bayi prematur. Imaturitas intestinalis salah satunya terkait dengan perubahan komponen sistem pertahanan usus termasuk peptida antimikroba dan sekretori imunoglobulin. ${ }^{8}$ Penelitian sebelumnya menunjukkan kadar hBD-2 tinja lebih rendah pada neonatus dengan UK 24 minggu dibandingkan usia kehamilan 42 minggu. Demikian pula kadar SIgA tinja, penelitian sebelumnya membuktikan usia kehamilan lebih dari 30 minggu berhubungan dengan kadar SlgA yang lebih tinggi dibandingkan usia kehamilan kurang dari 30 minggu. 9,10

Ketika dalam kandungan, gastrointestinal janin diisi oleh cairan ketuban steril, persalinan memicu terjadinya kolonisasi bakteri. Meskipun demikian, mekanisme pertahanan bawaan yang kuat mampu melindungi neonatus dari infeksi. Imunoglobulin dan peptida antimikroba terbukti berperan dalam proses inflamasi terutama pada saluran cerna. ${ }^{11}$ Salah satu imunoglobulin yang berperan penting yakni sekretori imunoglobulin A.
Sekretori IgA berfungsi sebagai garis pertahanan pertama dalam melindungi epitel usus dari enterik toksin dan mikroorganisme patogen melalui proses yang dikenal sebagai eksklusi imun dimana SlgA menginisiasi clearance antigen dan mikroorganisme patogen dari lumen usus dengan menghalangi akses ke reseptor epitel, menjebak dalam lendir, dan memfasilitasi pengeluarannya dengan aktivitas peristaltik dan mukosiliar. ${ }^{12}$ Selain itu, komponen sekretori (SC) yang melekat pada IgA menjadikan SIgA bersifat lebih stabil (tidak mudah dihancurkan oleh enzim proteolitik) dibandingkan imunoglobulin lainnya sehingga dapat dikatakan pengukuran kadar SlgA tinja mencerminkan kompetensi respons imun mukosa gastrointestinal. Beberapa penelitian sebelumnya telah membuktikan bahwa kadar SlgA dapat terdeteksi pada spesimen tinja, terutama neonatus yang mendapatkan ASI di minggu pertama kehidupan.13,14 Demikian pula penelitian oleh Hayati et al. (2016), yang membuktikan SIgA dideteksi pada tinja dan memiliki hubungan erat dengan kemampuan saluran cerna untuk melakukan netralisasi serta clearing mikroba patogen. ${ }^{15}$ Sejalan dengan studi lain dimana SIgA tinja terdeteksi pada semua bayi sejak lahir. ${ }^{16}$

Penelitian ini dilakukan pada neonatus usia empat belas hari dan diperoleh hasil SlgA tinja tertinggi $2091,2 \mu \mathrm{g} / \mathrm{mL}$ yang berasal dari neonatus yang mengonsumsi air susu ibu saja. Nilai tersebut sesuai dengan penelitian Maruyama et al. (2009) yang menunjukkan kadar SlgA maksimal pada neonatus yang mengonsumsi ASI dalam satu bulan pertama dapat mencapai $4500 \mu \mathrm{g} / \mathrm{mL}$ dan sedikit lebih tinggi dibandingkan penelitian Hayati et al. (2016) yang menjabarkan nilai SIgA normal yakni 510$2040 \mu \mathrm{g} / \mathrm{mL} .{ }^{15,17}$

Kadar SlgA tinja pada kelompok neonatus yang mengonsumsi ASI $(1541,92+418,69 \mu \mathrm{g} / \mathrm{mL})$ lebih tinggi secara signifikan dibanding kedua kelompok lainnya, 
yakni ASI dan susu formula $(826,23 \pm 311,58$ $\mu \mathrm{g} / \mathrm{mL}$ ) serta susu formula saja $(387,66 \pm 135,96 \mu \mathrm{g} / \mathrm{mL})$ dengan nilai $p=$ 0,000 . Hasil ini sejalan dengan penelitian pendahuluan oleh Hayati et al. (2016) dimana kadar SIgA tinja pada neonatus usia $<2$ bulan lebih tinggi pada kelompok yang mengonsumsi air susu ibu dibandingkan susu formula baik usia 2 minggu, 4 minggu, maupun 8 minggu. ${ }^{15}$ Studi lain yang dilakukan pada 34 neonatus sehat membuktikan bahwa neonatus dengan air susu ibu memiliki kadar SlgA tinja yang jauh lebih tinggi dibandingkan yang mengonsumsi susu formula. ${ }^{18}$

Peneltian oleh Kuitunen \& Savilahti (2015), menjabarkan bahwa kadar SlgA tinja pada kelompok yang mengonsumsi air susu ibu lebih tinggi 3-9 kali dibandingkan yang mengonsumsi susu formula saja. Hal tersebut terjadi diduga karena beberapa mekanisme yaitu (1) ASI mampu menstimulasi produksi SlgA dari mukosa gastrointestinal; (2) adanya IgA ASI yang tersimpan di kolon; atau (3) adanya substansi bioaktif lain dari ASI yang mampu meningkatkan produksi SlgA seperti TH17. Demikian pula Bridgman et al. (2016), yang menjelaskan kadar $\lg A$ tinja pada neonatus yang mengonsumsi ASI saja lebih tinggi delapan kali dibandingkan neonatus yang mengonsumsi susu formula saja. 14,16

Meskipun sekretori imunoglobulin A terdeteksi pada spesimen tinja neonatus yang mengonsumsi ASI, kemampuan neonatus untuk menghasilkan IgA pada periode waktu tersebut masih sangat terbatas. Adapun imunitas pasif yang didapatkan (berupa $\lg A$ dan peptida antimikroba) berasal dari ASI, terutama kolostrum. Selain itu, peneliti juga membuktikan bahwa pemberian ASI berhubungan signifikan secara statistik dengan peningkatan kadar SIgA tinja. Penelitian oleh Kuitunen \& Savilahti (2015), membuktikan penurunan kadar SIgA ASI berbanding lurus dengan penurunan kadar SlgA tinja. ${ }^{14,16} \mathrm{Hal}$ tersebut dapat dijelaskan dengan teori oleh Maruyama et al. (2009) bahwa imunoglobulin A disekitar folikel limfoid Peyer's patches baru muncul pada usia 5 hari serta IgA-immunocytes mukosa dapat terdeteksi di usus neonatus pada minggu pertama dan kedua kehidupan. ${ }^{17}$

Antigen bakteri yang mampu melewati pertahanan barier akan terdeteksi oleh pattern recognition receptor (PRR) dan selanjutnya mengaktivasi toll like receptor (TLR) yang diekspresikan oleh sel imun bawaan. Kedua mekanisme tersebut menginduksi produksi sitokin proinflamasi. Dalam keadaan normal, usus dapat mencegah reaksi imunitas yang berlebihan pada saluran cerna dengan memproduksi protein maupun sitokin antiinflamasi salah satunya yakni peptida antimikroba. ${ }^{19}$ Beberapa peptida telah diidentifikasi dalam mekonium dan tinja neonatus selama minggu pertama kehidupan, menunjukkan adanya partisipasi peptida sebagai barrier usus terhadap infeksi. Satu kelas penting dari peptida antimikroba adalah keluarga defensin. Beberapa penelitian pendahuluan telah membuktikan bahwa hBD-2 dapat dengan mudah terdeteksi pada tinja, seperti penelitian oleh Campeotto et al. (2010) yang mendeteksi hBD-2 pada tinja neonatus usia tiga hari. Demikian pula dengan Corebima (2017) yang meneliti kandungan hBD-2 neonatus pada usia 14 hari.., 20

Human beta defensin-2 tinja yang terdeteksi paling rendah pada penelitian ini adalah $151,775 \mathrm{ng} / \mathrm{mL}$, berasal dari kelompok neonatus prematur yang mengonsumsi ASI saja. Nilai tersebut serupa dengan penelitian sebelumnya oleh Campeotto et al. (2010) yang menjabarkan kadar hBD-2 tinja pada neonatus sehat usia 14 hari adalah 30-154 ng/mL. ${ }^{5}$ Penelitian ini membuktikan bahwa terdapat perbedaan mean kadar hBD-2 tinja neonatus prematur pada ketiga kelompok yang bermakna secara statistik. 
Mean kadar hBD-2 tinja neonatus pada kelompok yang mengonsumsi ASI saja yakni $204,47+40,63 \mathrm{ng} / \mathrm{mL}$ secara spesifik lebih rendah dibandingkan kelompok yang mengonsumsi kombinasi ASI dan susu formula $(351,66 \pm 38,19 \mathrm{ng} / \mathrm{mL})$, serta susu formula saja $(375,73+69,13 \mathrm{ng} / \mathrm{mL})$. Hasil tersebut sesuai dengan penelitian pendahuluan oleh Corebima (2017), yang menunjukkan kadar hBD-2 tinja neonatus pada kelompok ASI saja jauh lebih rendah dibandingkan kelompok susu formula saja. ${ }^{20}$ Kadar hBD-2 tertinggi didapatkan pada neonatus usia empat belas hari yang mengonsumsi susu formula saja yaitu $492 \mathrm{ng} /$ $\mathrm{mL}$. Nilai tersebut lebih tinggi dari kadar hBD2 neonatus prematur sehat pada penelitian oleh Campeotto et al. (2010) yaitu 30-154 $\mathrm{ng} / \mathrm{mL}$ dan termasuk dalam kadar hBD-2 neonatus yang mengalami intestinal distress pada penelitian yang sama yakni 2-1271 ng/ $\mathrm{mL}$. Bila dibandingkan dengan penelitian oleh Jenke et al. (2012), nilai hBD-2 tinja tertinggi pada penelitian ini adalah empat kali lipat (5-109 ng/mL).5,6 Kadar hBD-2 tinja terkait dengan efek bakterisidal, Routsias et al. (2010) menemukan kadar hBD-2 tinja yang dapat membunuh bakteri tidak resisten terhadap antibiotika adalah $3,25-4,5 \mathrm{mcg} /$ $\mathrm{mL}$, sedangkan kadar yang dibutuhkan untuk membunuh bakteri wild type adalah 3,9-9,35 $\mathrm{mcg} / \mathrm{mL}$. Selain itu, penelitian oleh Baricelli et al. (2015) menunjukkan aktivitas antimikrobial adalah $0,25 \mathrm{mcg} / \mathrm{mL}$ pada S. mercescen, 0,5 $\mathrm{mcg} / \mathrm{mL}$ pada $P$. aeruginosa, dan $4 \mathrm{mcg} / \mathrm{mL}$ pada Acinobactere baumannii. Kadar hBD-2 yang terstimulasi dari usus masih terlalu rendah untuk mencapai efek bakterisidal pada infeksi berat, dalam hal ini ASI berperan meningkatkan kadar hBD-2. ${ }^{21,22}$

Rata rata nilai $\mathrm{hBD}-2$ tinja neonatus prematur kelompok susu formula saja secara statistik menunjukkan perbedaan yang tidak bermakna dengan rata-rata kelompok kombinasi ASI dan susu formula saja $(p=$ 0,463), namun berbeda signifikan dibandingkan kelompok ASI saja. Sejalan dengan penelitian Arisanti \& Wibowo (2019), bahwa kadar marker inflamasi tinja pada neonatus yang mengonsumsi ASI dan susu formula tidak berbeda signifikan dibandingkan dengan yang mengonsumsi susu formula saja. Selain itu, penelitian oleh Corebima (2017) juga menunjukkan kadar hBD-2 tinja neonatus dengan paparan susu formula baik menggunakan ASI maupun tidak, tidak menunjukkan perbedaan signifikan, sebaliknya bila dibandingkan dengan kelompok ASI saja menunjukkan perbedaan yang bermakna.20,23 Hal tersebut mampu dijelaskan oleh Willems et al. (2015), bahwa pemberian susu formula dapat menginduksi faktor proinflammatory meskipun belum didapatkan tanda klinis inflamasi, sedangkan ASI berperan menekan inflamasi termasuk yang terjadi pada saluran cerna bayi. ${ }^{24}$

Penelitian ini dilakukan secara crosssectional sehingga tidak mampu menjelaskan hubungan kadar SlgA tinja terhadap inflamasi saluran cerna (dinilai dari kadar hBD-2 tinja maupun luaran klinis). Namun, dari 13 neonatus pada kelompok yang mendapatkan ASI saja hanya dua yang tidak menunjukkan gejala saluran cerna, sedangkan 11 neonatus lainnya didapatkan dengan gejala klinis muntah, perut membesar, maupun keduanya. Bahkan, neonatus dengan kadar SlgA tertinggi didapatkan dengan keluhan muntah dan perut membesar dengan kadar hBD-2 tinja $154 \mathrm{ng} / \mathrm{mL}$ yang bukan nilai terendah dalam penelitian ini (nilai terendah 151,775 $\mathrm{ng} / \mathrm{mL}$ ) meskipun masih termasuk rentang normal berdasarkan Campeotto et al. (2010). Kondisi tersebut dapat dijelaskan oleh Gopalakrishna et al. (2019) bahwa kadar SlgA yang terdeteksi pada tinja tidak mencerminkan kemampuan untuk berikatan dengan bakteri patogen. 
Pada neonatus dengan inflamasi saluran cerna (pada penelitian ini dengan subjek enterokolitis nekrotikan) diketahui memiliki ikatan yang lemah antara IgA dengan bakteri. Adapun hal yang mempengaruhi kualitas SlgA pada neonatus selain pemberian nutrisi ASI dan kualitas SIgA ASI ibu adalah maturitas imunitas saluran cerna. $5,13,25$

Beberapa keterbatasan dalam penelitian ini: (1) sampel diperoleh secara consecutive sampling dengan keterbatasan waktu penelitian, hal ini dapat mempengaruhi representasi sampel penelitian terhadap populasi umum, (2) masih didapatkan beberapa faktor perancu yang sulit dihindari dan dapat memengaruhi hasil dalam penelitian seperti cara penyimpanan dan transpor ASI dari ibu ke petugas perinatologi, penggunaan orogastrik, pemberian antibiotik, dan ruang perawatan di perinatologi (infeksi atau non-infeksi) selama pengamatan, (4) mekanisme antiinflamasi juga diperankan oleh sitokin antiinflamasi lainnya yang terinduksi, sehingga dapat memengaruhi kadar human B defensin-2 yang dinilai, (5) tidak dilakukan pemeriksaan flowcytometry untuk menilai efektivitasi SIgA terhadap kemampuan coated bacteria.

\section{Kesimpulan}

Kadar sekretori $\lg$ A tinja neonatus prematur yang mengonsumsi ASI saja lebih tinggi dibandingkan neonatus permatur yang mengonsumsi ASI dan susu formula maupun susu formula saja. Kadar human beta defensin-2 tinja neonatus prematur yang mengonsumsi ASI saja lebih rendah dibandingkan neonatus prematur yang mengonsumsi ASI dan susu formula maupun susu formula saja.

\section{Daftar Pustaka}

1. Spearman PW, Camacho-Gonzalez A, Stoll BJ. Neonatal Infectious Diseases:
Evaluation of Neonatal Sepsis. Pediatr Clin North Am. 2013; 60:367-389.

2. Soeorg $H$, Huik $K$, Parm U, IImoja ML, Metelskaja N, Metsvaht T, Lutsar I. Genetic Relatedness of Coagulase-Negative Staphylococci from Gastrointestinal Tract and Blood of Preterm Neonates with LateOnset Sepsis. Pediatr Infect Dis J. 2013; 32:389-393.

3. Frost B. Maternal Breast Milk Transforming Growth Factor Beta and Feeding Intolerance in Preterm Infants. Journal Pediatr Res. 2014; 76(4):386-393.

4. Corthesy B. Role of Secretory Immunoglobulin A and Secretory Component in the Protection of Mucosal Surfaces. Future Microbiol. 2010; 5 (5):817-829.

5. Campeotto F, Baldassarre M, Laforgia N, Viallon V, Kalach N, Amati L, Butel MJ, Dupont C, Kapel N. Fecal Expression of Human Beta Defensin 2 Following Birth. Neonatology. 2010; 98:365-369.

6. Jenke AC, Zilbauer M, Postberg J, Wirth $S$. Human-Defensin 2 Expression in ELBW Infants with Severe Necrotizing Enterocolitis. Pediatr Res. 2012; 72:51320.

7. Maastrup $\mathrm{R}$, Hansen BM, Kronborg $H$, Bojesen $S N$, Hallum $K$, Fradsen $A$, Kyhnaeb A, Svarer I, Hallstrom I. Factor Associated with Exclusive Breastfeeding of Preterm Infants: Result from a Prespective National Cohort Study. Plos One. 2014; 9(2):1-9.

8. Good M, Sodhi CP, Hackam DJ. Evidence -Based Feeding Strategies Before and After the Development of Necrotizing Enterocolitis. Expert Review of Clinical Immunology. 2014; 2:1-10.

9. Markus R, Georg H, Michael G, Thorsten F, Anja T, Tobias W, Henrik K. Influence of Gestational Age, Caesarean Section, and Type of Feeding on Fecal Human Beta Defensin 2 and Tumor Necrosis Factor Alfa. Journal of Pediatric Gastroenterology and Nutrition. 2010; 51(1):103-105. 
10. Rodriguez GG, Licona NA, Benitez LD, Sabanero GB, Magdaleno DC, Padilla RA, Ramirez EG. Single Strain Versus Meltispecies Probiotic on Necrotizing Enterocolitis and Faecal IgA Level in Very Low Birth Weight Preterm Neonates: A Randomized Clinical Trial. Pediatric and Neonatology. 2019; 20:564-569.

11. Neu J, Walker WA. Necrotizing Enterocolitis. New England Journal of Medicine. 2011; 364: 255-264.

12. Mantis NJ, Rol N, Cothersy B. Secretory IgA's Complex Roles in Immunity and Mucosal Homeostasis in the Gut. Mucosal Immunol. 2011; 4(6):603-611.

13. Retnaningtyas $P$, Sudarmo $S M$, Harsono A, Damanik SM. Effect of Probiotic on the Fecal slgA Level in Preterm Infants (A Randomized Double-Blind Placebo Control Study). Paediatr Indones. 2008; 48(4):247-252.

14. Bridgman SL, Konya T, Azad MB, Sears MR, Becker AB, Turvey SE, Mandhane PJ, Subbarao P, Scott JA, Field CJ, Kozyrskyj. Infant Gut Immunity: a Preliminary Study of IgA Association with Breastfeeding. Journal of Development Origin of Health and Disease. 2016; 7 (1):68-72.

15. Hayati N, Kadim M, Mangunatmadja I, Soedibyo S, Ifran EB, Sjakti HA. Gut Wall Integrity in Exclusively Breastfed vs Formula Fed Infants. Paediatr Indones. 2016; 56(4):1-6.

16. Kuitunen M, Savilahti E. Mucosal IgA, Mucosal Cow's Milk Antibodies, Serum Cow's Milk Antibodies and Gastrointestinal Permeability in Infant. Pediatr Allergy Immunol. 2015; 6:30-35.
17. Maruyama $K$, Hida $M$, Kohgo $T$, Fukunaga $\mathrm{Y}$. Changes in Salivary and Faecal Secretory IgA in Infants under Different Feeding Regimens. Pediatrics International. 2009; 51:342-345.

18. Kumagai $H$, Maisawa $S$, Tanaka $M$, Takahashi M, Takasago Y, Nishijima A, Watanabe S. Intestinal Microbiota and Secretory Immunoglobulin $A$ in Feces of Exclusively Breast Fed Infants with Blood Streaked Stools. Microbiol Immunol. 2012; 56:657-663.

19. Maheswari A. Immunological and Hematological Abnormalities in Necrotizing Enterocolitis. Clin Perinatol. 2016; 42(3):567-585.

20. Corebima B. Kadar Human Beta Defensin dalam Tinja dan Pola Mikrobiota Saluran Cerna pada Neonatus Kurang Bulan yang Mendapat ASI, Susu Formula, maupun Kombinasi. Fakultas Kedokteran Universitas Indonesia. 2017.

21. Routsias JG, Karagounis $P$, Parvulesku G, Legakis NJ, Tsakris A. In Vitro Bactericidal Activity of Human Beta Defensin 2 againts Nosocomial Strain. $J$ Peptide. 2010; 31:1654-1660.

22. Baricelli J, Rocafull MA, Vázquez $D$, Bastidas B, Báez-Ramirez E, Thomas LE. Beta-Defensin-2 in Breast Milk Displays a Broad Antimicrobial Activity against Pathogenic Bacteria. J Pediatr (Rio J). 2015; 91:36-43.

23. Arianti D, Wibowo S. Fecal Calprotectin Level of Breast Milk-Formula vs Formula Feeding in Preterm and Low Birth Weight Neonates with Necrotizing Enterocolitis. Journal of Tropical Life Science. 2019; 9 (1):29-33. 
24. Willems R, Rybicki V, Jiang P, Sangild PT, 25. Gopalakrishna KP, Macadangdang BR, Shen RL, Hensel KO, Wirth S, Postberg J, Rogers MB, Tometich JT, Firek BA, Baker Jenke AC. Introduction of Formula Feeding Induces Structure in the Intestine of Preterm Pigs. Mol Cell Pediatr. 2015; 2 $\mathrm{R}$, Ji J, Burr AHP, Ma C, Good M, Morowitz MJ, Hand TW. Maternal IgA (1):A6.

Protects againts the Development of Necrotizing Enterocolitis in Preterm Infants. Nature Medicine. 2019; 25:11101115. 